\title{
Evaluation of the Effects of Biofield Energy Healing Based Herbomineral Formulation on Various Biomarkers in Male Sprague Dawley Rats: Potential Role of the Trivedi Effect ${ }^{\circledR}$
}

\author{
Mahendra Kumar Trivedi ${ }^{1}$, Alice Branton ${ }^{1}$, Dahryn Trivedi ${ }^{1}$, Gopal Nayak ${ }^{1}$, \\ Barry Dean Wellborn ${ }^{1}$, Deborah Lea Smith ${ }^{1}$, Dezi Ann Koster ${ }^{1}$, Elizabeth Patric ${ }^{1}$, Jagdish Singh ${ }^{1}$, \\ Kathleen Starr Vagt ${ }^{1}$, Krista Joanne Callas ${ }^{1}$, Sambhu Charan Mondal ${ }^{2}$, Snehasis Jana ${ }^{2}$, \\ ${ }^{1}$ Trivedi Global, Inc., Henderson, USA \\ ${ }^{2}$ Trivedi Science Research Laboratory Pvt. Ltd., Bhopal, India
}

Email address:

publication@trivedieffect.com (S. Jana)

${ }^{*}$ Corresponding author

To cite this article:

Mahendra Kumar Trivedi, Alice Branton, Dahryn Trivedi, Gopal Nayak, Barry Dean Wellborn, Deborah Lea Smith, Dezi Ann Koster, Elizabeth Patric, Jagdish Singh, Kathleen Starr Vagt, Krista Joanne Callas, Sambhu Charan Mondal, Snehasis Jana. Evaluation of the Effects of Biofield Energy Healing Based Herbomineral Formulation on Various Biomarkers in Male Sprague Dawley Rats: Potential Role of the Trivedi Effect ${ }^{\circledR}$. International Journal of Pharmacy and Chemistry. Vol. 3, No. 6, 2017, pp. 99-108. doi: 10.11648/j.ijpc.20170306.16

Received: October 30, 2017; Accepted: November 17, 2017; Published: December 5, 2017

\begin{abstract}
A new proprietary herbomineral formulation was formulated, consisting of essential ingredients viz. herbal root extract ashwagandha and minerals (zinc, magnesium, and selenium). The aim of the study was to evaluate the immunomodulatory potential of Energy of Consciousness Healing (The Trivedi Effect ${ }^{\mathbb{B}}$ ) Treatment on the herbomineral formulation in male Sprague Dawley rats. The test formulation was divided into two parts. One part was denoted as the control without Biofield Energy Healing Treatment, while the other part was defined as the Biofield Energy Treated sample, which received the Biofield Energy Healing Treatment remotely from seven renowned Biofield Energy Healers. Additionally, one group of animals was also received Biofield Energy Treatment per se (day -15) by Biofield Energy Healers under similar conditions. The IgM, IgG, $\mathrm{CD} 4^{+}$, and $\mathrm{CD}^{+}$were altered in the Biofield Energy Treated test formulation (G4) compared to the disease control (G2). TLC was significantly increased by $19.35 \%$ in the G4 compared to the G2. Neutrophil was significantly increased by $31.53 \%, 29.73 \%, 31.53 \%$, and $33.84 \%$ in the G4, untreated test formulation (G5), G6, and G7, respectively compared to the G2. The levels of total cholesterol (TC), triglycerides (TG), and very low density lipoprotein (VLDL) were significantly lowered by $18.18 \%(p \leq 0.01), 46.33 \%(p \leq 0.01)$, and $46.41 \%(p \leq 0.01)$, respectively in the G4 compared to the G2. Additionally, the levels of TC, TG, low density lipoprotein (LDL), and VLDL were significantly reduced by $25.50 \%$ $(p \leq 0.001), 96.39 \%(p \leq 0.001), 13.91 \%$, and $55.08 \%(p \leq 0.001)$, respectively in the G6 compared to the G2. Alkaline phosphatase (ALP) was significantly reduced by $33.65 \%(p \leq 0.001)$ in the G4 compared to the G2. Moreover, the levels of serum glutamate oxaloacetate transaminase (SGOT), serum glutamate pyruvate transaminase (SGPT), ALP, and creatine kinase myocardium band (CK-MB) were significantly decreased by $29.44 \%(p \leq 0.05), 25.54 \%(p \leq 0.01), 27.97 \%(p \leq 0.01)$, and $36.07 \%(p \leq 0.01)$, respectively in the G7 group compared to the G2. Testosterone was significantly increased by $83.68 \%$, $305.90 \%, 1271.03 \%(p<0.001)$ and $745.35 \%(p<0.05)$ in the G4, G5, G6 and G7, respectively compared to the G2. The level of catalase enzyme was significantly increased by $57.91 \%(p<0.01)$ and $98.51 \%(p<0.001)$ in Biofield Energy Treatment per se at day -15 (G6) and Biofield Energy Treated test formulation at day -15 (G7), respectively compared to the G2. Overall, results suggested that the Biofield Energy Treated herbomineral formulation and Biofield Energy Treatment per se can be used for autoimmune and inflammatory diseases, stress management and prevention, and anti-aging by improving overall health.
\end{abstract}

Keywords: Biofield Energy Healing Treatment, Biofield Energy Healers, The Trivedi Effect ${ }^{\circledR}$, Immunomodulation, Herbomineral Formulation, Antioxidant, Anti-aging, Inflammatory Disease and Stress Management 


\section{Introduction}

An herbomineral products have been accepted worldwide against many health related disorders, due to their significant immunomodulatory potential. However, the action of herbominerals as an immune booster make it a unique compared with other available nutraceutical products. Overall, Quality of Life $(\mathrm{QoL})$ can be improved by maintaining the organic resistance of the body. It was reported that secondary metabolites of plants extract and minerals play an important role in the immunomodulatory action [1-3]. An herbal medicines and minerals are the major targeted product to modulate the immune system due to its low toxicity profile compared with the synthetic drugs against infections $[4,5]$. The main role of existed conventional medicine was to diagnose and treat the disease, but in $21^{\text {st }}$ century the primary goal of nature-based herbomineral formulation is predictive and prevention of diseases. Biomarkers are the biological measurements, which can be utilized to predict the severity of disease and to recognize the forward detection of disease [6]. It was well established that the immune biomarkers were used for the early diagnosis and evaluation of target organ damage in most of non-autoimmune disease such as diabetes mellitus, hypertension, arteriosclerosis etc. [7, 8]. The early diagnosis of biomarker is a biologic indicator in clinical practice that indicate the risk of specific disorders, its progression, and the relative risk/benefit related with the specific therapy, plays a central role in the selection of the most effective treatment [9]. The new proprietary herbomineral formulation containing four ingredients; mixture of minerals (zinc chloride, magnesium gluconate hydrate, and sodium selenate) and an herbal extract (ashwagandha root extract). Each constituent of this formulation is commonly used as nutraceutical supplement [10-12]. The immunomodulatory agents have the ability to normalize or modulate pathophysiological processes $[13,14]$. Various studies have reported anti-inflammatory, antiarthritic, antibiotic, antitumour immunomodulatory and central nervous system effects of withanolides $[15,16]$. Zinc plays a major role in most of the biochemical reactions in living organism due to its enzyme catalyzing activity. Most of the enzymatic reaction are zinc dependent. It also plays a key role for regulation of sex hormones and in the immune system $[17,18]$. Selenium also plays a major role for immunomodulation by alterations of cluster differentiation $\left(\mathrm{CD}^{+}\right)$lymphocyte function [19] Magnesium reduces the production of inflammatory cytokine through activation of $N F-\kappa B$ pathways, which is a novel innate immunomodulatory mechanism [20]. It is observed that acute stress may enhance immune response, whereas chronic stress may suppress the immune system [21].

Scientific research has been reported that the combination of minerals and herbal medicines found to exhibit significant immunomodulatory action [22]. An herbomineral formulations can be used for better therapeutic effect in immune compromised patients that are affected by the cardiovascular diseases, age, stress related diseases, cancer, and autoimmune disorders. Along with the herbomineral formulations, the Biofield Energy Healers in this study have used Energy Medicine (Biofield Energy Healing Treatment) as a complementary and alternative approach to study the impact of Biofield Energy Healing Treatment on the herbomineral formulation for its immunomodulatory potential in male Sprague Dawley rats.

Amidst many Complementary and Alternative Medicine (CAM) therapies, there have been an extensive number of scientific reports that showed Biofield Therapy (or Healing Modalities) as preferred models of treatment with several benefits to enhance physical, mental and emotional human wellness. The National Center of Complementary and Integrative Health $(\mathrm{NCCIH})$ has recognized and accepted Biofield Energy Healing as a CAM health care approach in addition to other therapies, medicines and practices such as natural products, deep breathing, yoga, Tai Chi, Qi Gong, chiropractic/osteopathic manipulation, meditation, massage, special diets, homeopathy, progressive relaxation, guided imagery, acupressure, acupuncture, relaxation techniques, hypnotherapy, healing touch, movement therapy, pilates, rolfing structural integration, mindfulness, Ayurvedic medicine, traditional Chinese herbs and medicines, naturopathy, essential oils, aromatherapy, Reiki, and cranial sacral therapy. Human Biofield Energy has subtle energy that has the capacity to work in an effective manner [23]. CAM therapies have been practiced worldwide with reported clinical benefits in different health disease profiles [24]. Biofield Energy Healing Treatment has gained rapid rapport as a holistic alternative and complementary medicine therapy that has significant impact on living organisms and nonliving materials without any adverse effects and in a manner that is more cost-effective than more conventional methods. Biofield Energy Treatment (The Trivedi Effect ${ }^{\circledR}$ ) results has been published in numerous peer-reviewed science journals with significant outcomes in many scientific fields such as cancer research [25], microbiology [26-28], genetics [29, 30], pharmaceutics [31, 32], nutraceuticals [33], organic compounds $[34,35]$, agricultural science $[36,37]$, and changing the structure of the atom in relation to various metals, ceramics, polymers and chemicals in materials science [38-40]. In this study, the authors sought to explore the impact of the Biofield Energy Treatment (The Trivedi Effect ${ }^{\mathbb{B}}$ ) on the given herbomineral formulation and Biofield Energy Treatment per se to the animals, which might improve the immunomodulatory function in cyclophosphamide induced immunosuppression in male Sprague Dawley rat model by identification of various immunity biomarkers.

\section{Materials and Methods}

\subsection{Chemicals and Reagents}

Ashwagandha root extract powder was procured from Sanat Products Ltd., India. Zinc chloride and magnesium (II) gluconate hydrate were procured from TCI, Japan. Sodium 
selenate was procured from Alfa Aesar, USA. Cyclophosphamide was used as inducing agent for immunosuppression was procured from Zydus Oncosciences India. Levamisole hydrochloride and sodium carboxymethyl cellulose (Na-CMC) were procured from Sigma-Aldrich, USA. All other chemicals used were of analytical grade available in India.

\subsection{Experimental Animals}

A total number of 56 healthy male Sprague Dawley rats, weighing between 220-250 grams, were used for the study ( $n=8$, in each group). The animals were purchased from $M / s$. Vivo Bio Tech Ltd., Hyderabad, India. Standard rodent diet was procured from M/s. Golden feeds, Mehrauli, New Delhi, India and provided ad libitum to all the groups of animals during the experiment under controlled conditions with a temperature of $22 \pm 3^{\circ} \mathrm{C}$, humidity of $30 \%$ to $70 \%$ and a 12 hour light/12-hour dark cycle. The animals were acclimatized for 5 days prior to the experiment, and all were accessed once daily for clinical signs, behaviors, morbidity and mortality. All the procedures were in strict accordance with the Guide for the Care and Use of Laboratory Animals published by the US National Institutes of Health. The approval of the Institutional Animal Ethics Committee that was obtained prior to carrying out the animal experiment.

\subsection{Biofield Energy Treatment Strategies}

The test formulation was divided into two parts. One part of the test formulation was treated with the Biofield Energy by renowned Biofield Energy Healers (also known as The Trivedi Effect ${ }^{\circledR}$ ) and coded as the Biofield Energy Treated formulation, while the second part of the test formulation did not receive any sort of treatment and was defined as the untreated test formulation. This Biofield Energy Treatment was provided through a group of seven Biofield Energy Healers who participated in this study and performed the Biofield Energy Treatment remotely were located in the U.S.A., while the test herbomineral formulation was located in the research laboratory of Dabur Research Foundation, New Delhi, India. Additionally, one group of animals was also received the Biofield Energy Treatment per se by the Biofield Energy Healers under similar conditions. This Biofield Energy Treatment was administered for 5 minutes through the Healer's unique Energy Transmission process remotely to the test formulation under laboratory conditions. None of the Biofield Energy Healers in this study visited the laboratory in person, nor had any contact with the herbomineral samples. Further, the control group was treated with a "sham" healer for comparative purpose. The sham healer did not have any knowledge about the Biofield Energy Treatment. After that, the Biofield Energy Treated and untreated samples were kept in similar sealed conditions and used for identification of immunological parameters.

\subsection{Antigen (Sheep RBC)}

The fresh sheep blood was collected aseptically from the jugular vein of a healthy sheep and transferred immediately to the heparinized tube. The collected erythrocytes were separated from plasma by centrifugation $\left(400 \mathrm{~g}, 10{ }^{\circ} \mathrm{C}, 10\right.$ minutes), washed twice with the normal saline and then further diluted in saline, which were analyzed using Hematology analyzer (Abbott Model-CD-3700). Based on the number of erythrocytes, the samples were further diluted (using saline) before injecting to the rats [41].

\subsection{Experimental Procedure}

After seven days of acclimatization, the animals were grouped based on the body weight. A total of seven groups (G) were included i.e. G1 to G7 with eight animals $(n=8)$ in each group. The animals were received cyclophosphamide in all the groups except $\mathrm{G} 1$ at a dose of $10 \mathrm{mg} / \mathrm{kg}$ in normal saline through intraperitoneal (i.p.) route 1 hour before administration of the test formulation, from day 1 to 13 . However, G1, G2, and G6 group's animals were administered with vehicle ( $0.5 \%$ carboxy methyl cellulose-sodium) via oral gavage. The G3 group animals received reference item, levamisole at a dose of $75 \mathrm{mg} / \mathrm{kg}$ body weight. The G4 group animals received Biofield Energy Treated test formulation at $1105.005 \mathrm{mg} / \mathrm{kg}$ b.wt, per-oral (p.o.), and the G5 animals received the untreated test formulation at the same dose by oral route. Further, the G6 group animals received only Biofield Energy Treatment per se at day -15, without test formulation, while G7 group animals received Biofield Energy Treated test formulation at day -15 . The freshly prepared suspensions of the Biofield Energy Treated and untreated test formulations were administered orally to the G4 and G5 groups, respectively at a dose of $1105.005 \mathrm{mg} / \mathrm{kg}$ from day 1 to day 25. However, Biofield Energy Treated test formulation was administered orally to the G7 group at same dose from day -15 to day 25 . The treatment was continued to all the tested groups ( $\mathrm{G} 1$ to $\mathrm{G} 7$ ) with $5 \mathrm{~mL} / \mathrm{kg}$ body weight dose volume.

However, all the animals (G1-G7) were challenged with sheep red blood cells (sRBC) $\left(0.5 \times 10^{9} / 100 \mathrm{gm}\right.$; i.p. $)$ on day 7 and 13, as the antigenic material to sensitize them for immunological studies. On day $13^{\text {th }}$ and $20^{\text {th }}$ the animals were bled and the samples were subjected to hemagglutination test for cellular $\left(\mathrm{CD}^{+}\right.$and $\left.\mathrm{CD} 8^{+}\right)$and humoral (IgG and $\mathrm{IgM}$ ) immune responses. On same day $20^{\text {th }}$, the animals were challenged with $\operatorname{sRBC}\left(0.5 \times 10^{9}\right.$ cells $/ 50 \mu \mathrm{L} / \mathrm{rat})$ in sub-planter region and on day $21^{\text {st }}(24$ hours) paw volume was measured to evaluate the cellular immune response. The body weight and feed consumption were measured daily before treatment. The animals were kept on overnight fasting on day 24 , followed by blood collection from retro-orbital plexus under isoflurane anaesthesia and the samples were subjected for haematology analysis, serum for biochemistry and hormone estimation. A portion of liver samples were snap frozen and stored in $-80^{\circ} \mathrm{C}$ for the estimation of anti-oxidant parameters (SOD, Catalase, and LPO). At the end of the study, animals were euthanized by $\mathrm{CO}_{2}$ asphyxiation as per in-house approved standard protocol. 


\subsection{Assessment of Cellular and Humoral Responses}

Humoral immune response, IgG and IgM were estimated using Mini Vidas, Biomeurix (French) from serum, using commercially available kits. Flow cytometry was used to evaluate the $\mathrm{CD}^{+}$and $\mathrm{CD}^{+}$cells in blood as a measure of the cellular immune response. The mean value was calculated for each group with SEM. The percent change in the Biofield Energy Treated group was calculated compared to the vehicle treatment group.

\subsection{Assessment of Hematology Parameters}

Hematological parameters such as total leukocyte count (TLC) and differential leukocyte counts (DLC) were analyzed using Hematology analyzer (Abbott Model-CD3700) in blood samples.

\subsection{Assessment of Lipid Profile and Hepatic Enzymes}

Glucose, total cholesterol (TC), triglycerides (TG), low density lipoprotein (LDL), high density lipoprotein (HDL), very low density lipoprotein (VLDL), alkaline phosphatase (ALP), serum glutamic oxaloacetic transaminase (SGOT), and serum glutamate-pyruvate transaminase (SGPT) were analyzed using serum $[42,43]$.

\subsection{Assessment of Sex Hormone}

Testosterone was analyzed in serum using commercial kits. The mean value was calculated for each group with SEM. The percent change in the Biofield Energy Treated group was calculated compared to the vehicle treatment group.

\section{A. IgM}

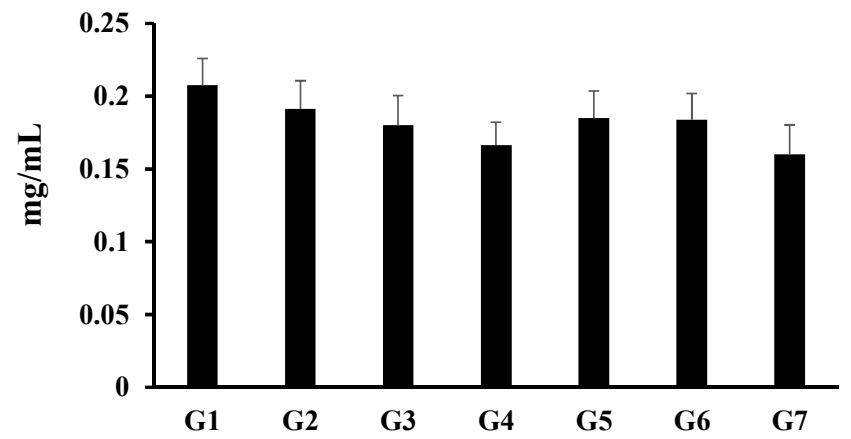

\subsection{Assessment of Antioxidant Profile by ELISA Assay}

Superoxide dismutase (SOD), catalase and lipid peroxidation (LPO) were analysed by ELISA assay using liver homogenate sample [44-46].

\subsection{Statistical Analysis}

The data were expressed as mean \pm standard error of mean (SEM) and subjected to statistical analysis using SigmaPlot (Version 11.0). Student's $t$-test was performed for comparison of the individual treatment group with control. The $p \leq 0.05$ was considered as statistically significant.

\section{Results and Discussion}

\subsection{Measurement of Humoral Immune Response}

The effects of Biofield Energy Treated and untreated test formulation on the levels of IgM and IgG in male SD rats are shown in the Figure 1. The animals administered with untreated test formulation (G5) showed $14.27 \%$ increase in IgG compared to the $\mathrm{G} 2$ group; while it was altered in the rest of the tested groups. The level of IgM was reduced by $13.07 \%, 3.92 \%$ and $16.34 \%$ in the Biofield Energy Treated test formulation (G4), Biofield Energy Treatment per se at day -15 (G6) and Biofield Energy Treated test formulation at day -15 (G7), respectively compared to the G2 group. Yamada et al. [47], had reported that ashwagandha to enhance the immune function by increasing immunoglobulin production. In this experiment the Biofield Energy Treated test formulation showed slight increase the level of IgG compared to the disease control group. The data was supported with the literature [47, 48].

\section{B. IgG}

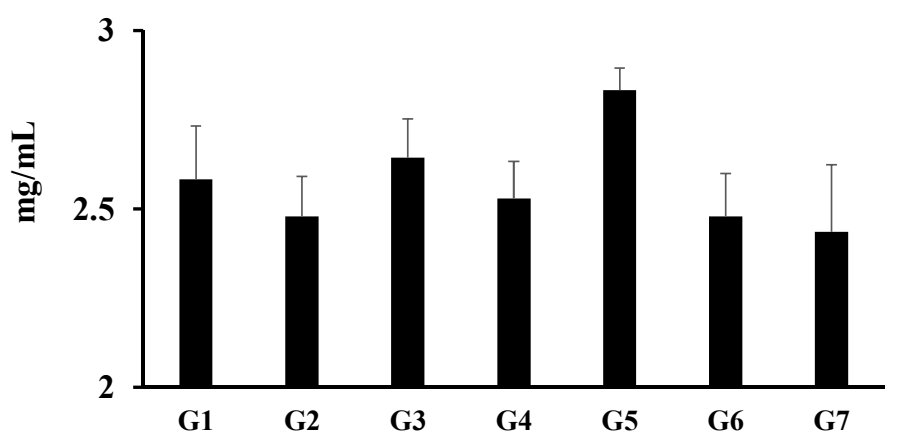

Figure 1. The effect of the test formulation on immunoglobulins (A. IgM and B. IgG) after 24 consecutive days of treatment in male SD rats. G1: Normal control; G2: Disease control; G3: Levamisole; G4: Biofield Energy Treated test formulation; G5: Untreated test formulation; G6: Biofield Energy Treatment per se at day -15; and G7: Biofield Energy Treated test formulation at day-15. All the values are represented as mean $\pm S E M(n=8)$.

\subsection{Measurement of Cellular Responses}

The effect of the test formulation on the levels of $\mathrm{CD}^{+}$and $\mathrm{CD} 8^{+}$in male SD rats is depicted in the Figure 2. The $\mathrm{CD}$ markers such as percentage of $\mathrm{CD} 4^{+}$and $\mathrm{CD} 8^{+}$cells were analyzed using whole blood. No substantial changes of $\mathrm{CD} 4{ }^{+}$counts were observed across the groups, while the $\mathrm{CD} 8^{+}$count was increased by $7.17 \%$ and $1.42 \%$ in the untreated test formulation (G5) and Biofield Energy Treatment per se (G6) respectively, compared to the disease control (G2). 
A. CD4 $^{+}$

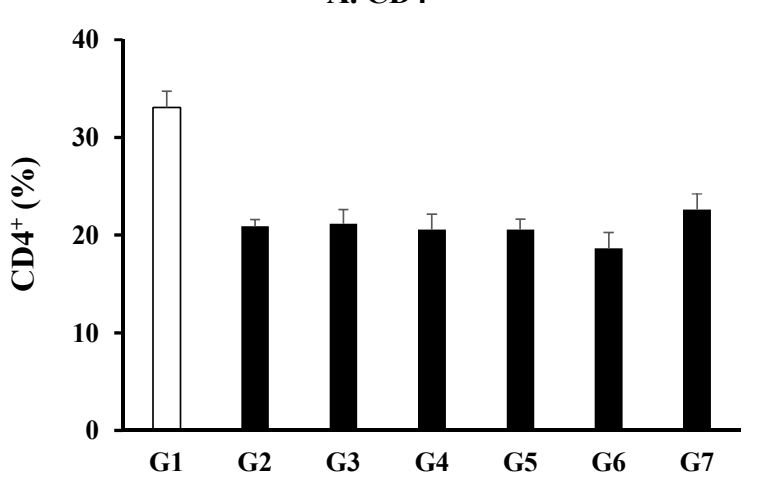

B. $\mathrm{CD8}^{+}$

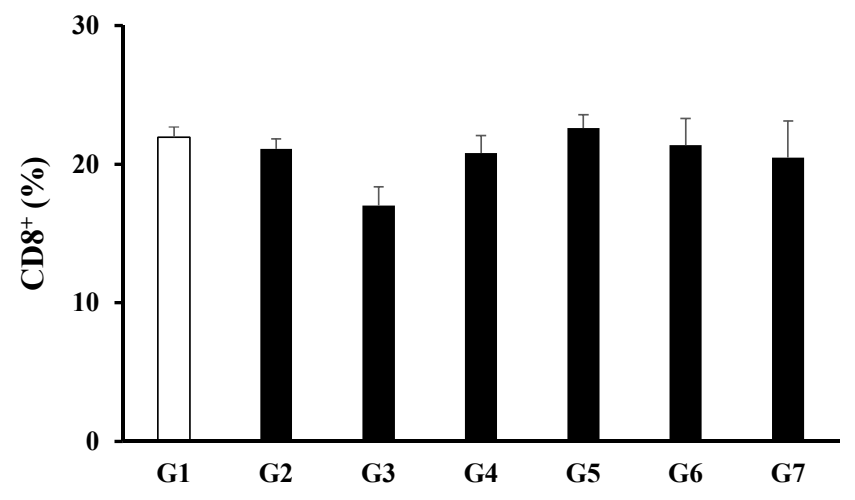

Figure 2. The effect of the test formulation on immunoglobulin cellular biomarkers $\left(A . C D 4^{+}\right.$and $\left.B . C D 8^{+}\right)$after 24 consecutive days of treatment in male SD rats. All the values are represented as mean $\pm \operatorname{SEM}(n=8)$.

\subsection{Assessment of Hematology Parameters}

The hematology parameters such as total and differential leucocytes counts are shown in the Table 1. The disease control group (G2) showed immunosuppression response was induced by cyclophosphamide as evident with the significant reduction of TLC, lymphocytes, and eosinophils by $29.43 \%$, $14.23 \%$, and $14.29 \%$, respectively compared to the normal control group (G1). The TLC was increased by $19.35 \%$ and $2.25 \%$ in the Biofield Energy Treated test formulation (G4) and Biofield Energy Treated test formulation at day -15 (G7), respectively compared to the disease control (G2). The level of neutrophils was significantly increased by $31.53 \%$, $29.73 \%, 31.53 \%$, and $33.84 \%$ in the Biofield Energy Treated test formulation (G4), untreated test formulation (G5), Biofield Energy Treatment per se (G6) at day -15, and Biofield Energy Treated test formulation at day -15 (G7), respectively compared to the disease control group (G2). The level of lymphocytes was reduced minimally in all the treated groups (G3 - G7) compared to the disease control (G2). The eosinophils level was increased by $8.67 \%, 8.67 \%, 16.67 \%$, and $14 \%$ in the Biofield Energy Treated test formulation (G4), untreated test formulation (G5), Biofield Energy Treated group per se (G6), and Biofield Energy Treated test formulation at day $-15(\mathrm{G} 7)$, respectively compared to the disease control (G2). The level of monocytes was decreased by $39.95 \%$ in the G4, G5, and G6; while increased by $8.68 \%$ in the Biofield Energy Treated test formulation group at day 15 (G7) compared to the disease control (G2). The positive control levamisole showed $26.13 \%$ and $16.67 \%$ increase in the levels of neutrophils and eosinophils, respectively compared to the disease control (G2). Eosinophils play the role of a beneficial modulatory element or an innocent bystander. Jung et al. [49], demonstrated that an increasing number of experimental observations indicated that eosinophils have multifunctional leukocytes that are involved in diverse inflammatory and physiologic immune responses. They have found the potential role of eosinophils as a modulators of the intestinal immune system [40]. This study therefore demonstrated that the Biofield Energy Treated test formulation (G4) showed an enhancement of the level of eosinophil to some extent compared to the G2 group. Another researcher reported the eosinophils and neutrophils show in the protective innate immune response [50]. Besides, the level of neutrophil was significantly increased by $31.53 \%$ in the G4 group compared to the G2 group.

Table 1. Effect of the test formulation on hematological parameters.

\begin{tabular}{|c|c|c|c|c|c|}
\hline Group & TLC $\left(10^{3} / \mathrm{mm}^{3}\right)$ & Neutrophils (\%) & Lymphocytes (\%) & Eosinophils (\%) & Monocyte (\%) \\
\hline G1 & $11.35 \pm 1.01$ & $17.88 \pm 2.27$ & $77.38 \pm 2.93$ & $1.75 \pm 0.49$ & $3.00 \pm 0.89$ \\
\hline G2 & $8.01 \pm 1.09$ & $27.75 \pm 3.27$ & $66.38 \pm 4.03$ & $1.50 \pm 0.19$ & $4.38 \pm 1.13$ \\
\hline G3 & $7.25 \pm 0.52$ & $35.00 \pm 4.67$ & $59.63 \pm 5.03$ & $1.75 \pm 0.25$ & $3.63 \pm 0.50$ \\
\hline G5 & $6.21 \pm 0.72$ & $36.00 \pm 2.18$ & $59.75 \pm 2.23$ & $1.63 \pm 0.18$ & $2.63 \pm 0.18$ \\
\hline G6 & $6.21 \pm 0.66$ & $36.50 \pm 1.94$ & $59.13 \pm 2.00$ & $1.75 \pm 0.25$ & $2.63 \pm 0.26$ \\
\hline G7 & $8.19 \pm 0.62$ & $37.14 \pm 3.25$ & $57.14 \pm 3.40$ & $1.71 \pm 0.42$ & $4.00 \pm 0.98$ \\
\hline
\end{tabular}

Analysis of hematological profile like total and differential (5 parts) counts of white blood corpuscles after consecutive 24 days of treatment of the test formulation in male SD rats. All the values are represented as mean \pm SEM ( $n=8)$. G: Group; G1: Normal control; G2: Disease control; G3: Levamisole; G4: Biofield Energy Treated test formulation; G5: Untreated test formulation; G6: Biofield Energy Treatment per se at day -15; and G7: Biofield Energy Treated test formulation at day -15 . TLC: Total leukocyte count; \%: Percentage

\subsection{Measurement of Glucose and Lipid Biomarkers}

The biochemical parameters i.e. glucose, lipid profile such as total cholesterol (TC), triglycerides (TG), high density lipoprotein (HDL), low density lipoprotein (LDL), and very low density lipoprotein (VLDL) are shown in the Table 2. The disease control group (G2) showed an increased level of LDL by $2.27 \%$ compared to the normal control group (G1). 
The levels of TC, TG, LDL, and VLDL were significantly reduced by $19.34 \%(p \leq 0.01), 21.94 \%, 20.85 \%(p \leq 0.01)$, and $22.15 \%$, respectively in the Biofield Energy Treated test formulation group (G4) compared to the disease control (G2). Besides, the levels of TC, TG, LDL, and VLDL were remarkably reduced by $18.18 \%(p \leq 0.01), 46.33 \%(p \leq 0.01)$, $7.05 \%$, and $46.41 \%(p \leq 0.01)$, respectively in the untreated test formulation group (G5) compared to the disease control (G2). Moreover, the levels of TC, TG, LDL, and VLDL were significantly reduced by $25.50 \% \quad(p \leq 0.001), \quad 96.39 \%$ $(p \leq 0.001), 13.91 \%$, and $55.08 \%(p \leq 0.001)$, respectively in the Biofield Energy Treated test formulation at day $-15(\mathrm{G} 7)$ compared to the disease control (G2). The positive control levamisole showed $17.84 \%, 8.09 \%, 21.89 \%$, and $7.63 \%$ increased the levels of TC, TG, LDL, and VLDL, respectively compared to the disease control (G2). The levels of HDL and glucose were altered in all the tested groups compared to the disease control $(\mathrm{G} 2)$.

Table 2. Effect of the test formulation on lipid biomarkers.

\begin{tabular}{|c|c|c|c|c|c|c|}
\hline Group & Glucose (mg/dL) & Total Cholesterol (mg/dL) & Triglyceride (mg/dL) & HDL (mg/dL) & LDL (mg/dL) & VLDL (mg/dL) \\
\hline G1 & $126.63 \pm 8.07$ & $91.48 \pm 4.75$ & $102.96 \pm 6.62$ & $27.39 \pm 1.43$ & $43.49 \pm 3.66$ & $20.57 \pm 1.32$ \\
\hline $\mathrm{G} 2$ & $117.06 \pm 6.03$ & $89.40 \pm 3.80$ & $87.10 \pm 11.03$ & $26.78 \pm 1.14$ & $45.08 \pm 1.99$ & $17.43 \pm 2.21$ \\
\hline G3 & $154.61 \pm 23.44$ & $105.35 \pm 5.26$ & $94.15 \pm 4.18$ & $31.58 \pm 1.58$ & $54.95 \pm 3.58$ & $18.76 \pm 0.80$ \\
\hline G4 & $147.10 \pm 10.57$ & $72.11 \pm 2.98^{* *}$ & $67.99 \pm 8.52$ & $21.62 \pm 0.89$ & $35.68 \pm 1.64 * *$ & $13.57 \pm 1.70$ \\
\hline G5 & $124.74 \pm 10.43$ & $73.15 \pm 3.92^{* *}$ & $46.75 \pm 4.85^{* *}$ & $21.91 \pm 1.18$ & $41.90 \pm 2.17$ & $9.34 \pm 0.97 * *$ \\
\hline G6 & $203.23 \pm 22.16$ & $86.48 \pm 3.75$ & $88.81 \pm 22.15$ & $25.90 \pm 1.12$ & $42.73 \pm 3.11$ & $17.77 \pm 4.43$ \\
\hline G7 & $127.73 \pm 8.83$ & $66.60 \pm 3.69^{* * *}$ & $39.14 \pm 4.31^{* * *}$ & $19.94 \pm 1.11$ & $38.81 \pm 2.33$ & $7.83 \pm 0.86^{* * *}$ \\
\hline
\end{tabular}

Analysis of lipid profile after consecutive 24 days of treatment of the test formulation in male SD rats. All the values are represented as mean \pm SEM $(n=8)$. Group; G1: Normal control; G2: Disease control; G3: Levamisole; G4: Biofield Energy Treated test formulation; G5: Untreated test formulation; G6: Biofield Energy Treatment per se at day -15; and G7: Biofield Energy Treated test formulation at day -15. HDL: High density lipoprotein; LDL: Low density lipoprotein; VLDL: Very low density lipoprotein; $\mathrm{mg} / \mathrm{dL}$ : Milligram per deciliter; $* * p \leq 0.01$ and ${ }^{* * *} p \leq 0.001$ (compared to the disease control).

\subsection{Measurement of Hepatic and Cardiac Biomarkers}

The effect of the test formulation on the hepatic and cardiac biomarkers are shown in the Table 3. The level of ALP was significantly reduced by $33.65 \%(p \leq 0.001)$ in the Biofield Energy Treated test formulation group (G4) compared to the disease control (G2). The SGOT, ALP, and CK-MB were significantly decreased by $10.74 \%, 29.85 \%$ $(p \leq 0.05)$, and $15.32 \%$, respectively in the Biofield Energy Treatment per se at day -15 (G6) compared to the G2 group. Moreover, the levels of SGOT, SGPT, ALP, and CK-MB were significantly decreased by $29.44 \%(p \leq 0.05), 25.54 \%$ $(p \leq 0.01), \quad 27.97 \% \quad(p \leq 0.01), \quad$ and $36.07 \% \quad(p \leq 0.01)$, respectively in the Biofield Energy Treated test formulation at day $-15(\mathrm{G} 7)$ compared to the $\mathrm{G} 2$ group. The ratio of $\mathrm{A} / \mathrm{G}$ was reduced minimally in the levamisole group (G3) compared to the G2 group. Rest of the biochemical parameters like total bilirubin, total protein, albumin, and globulin did not show any significant changes in all the tested groups compared to the G2 group. Alteration of immune functions are associated with the elevation of liver enzymes in various disorders. The Biofield Energy Treated test formulation group (G4) showed decreased level of ALP by $33.65 \%$ compared to the G2 group, which would be beneficial in immunodeficiency patients. Thus, it is assumed that the reduction of ALP might be due to the effect of the Biofield Energy Healing Treatment to the test formulation. It had been shown that ashwagandha reduced the level of ALP level in rats. The current data were also corroborated with the reported literature [51].

Table 3. Effect of the test formulation on hepatic and cardiac biomarkers in male rats.

\begin{tabular}{|c|c|c|c|c|c|c|c|c|c|}
\hline Group & SGOT (U/L) & SGPT (U/L) & $\operatorname{ALP}(\mathbf{U} / \mathbf{L})$ & CK-MB (U/L) & $\begin{array}{l}\text { Tot. BL } \\
\text { (mg/dL) }\end{array}$ & $\begin{array}{l}\text { Tot. Prot. } \\
\text { (g/dL) }\end{array}$ & $A(g / d L)$ & $G(g / d L)$ & A/G ratio \\
\hline G1 & $201.68 \pm 13.31$ & $48.91 \pm 3.79$ & $306.88 \pm 28.44$ & $828.19 \pm 82.35$ & $0.13 \pm 0.01$ & $8.17 \pm 0.06$ & $3.82 \pm 0.03$ & $4.35 \pm 0.05$ & $0.88 \pm 0.01$ \\
\hline $\mathrm{G} 2$ & $170.58 \pm 10.68$ & $42.79 \pm 3.15$ & $305.05 \pm 21.10$ & $825.93 \pm 61.10$ & $0.14 \pm 0.01$ & $7.81 \pm 0.17$ & $3.78 \pm 0.03$ & $4.03 \pm 0.16$ & $0.95 \pm 0.04$ \\
\hline G3 & $164.26 \pm 10.57$ & $52.31 \pm 1.73$ & $243.66 \pm 9.83^{*}$ & $719.13 \pm 73.17$ & $0.14 \pm 0.01$ & $8.06 \pm 0.23$ & $3.73 \pm 0.06$ & $4.96 \pm 0.58$ & $0.80 \pm 0.06$ \\
\hline G4 & $197.01 \pm 27.31$ & $44.44 \pm 6.93$ & $202.41 \pm 14.16^{* * *}$ & $969.43 \pm 86.79$ & $0.15 \pm 0.02$ & $7.62 \pm 0.15$ & $3.70 \pm 0.04$ & $3.92 \pm 0.13$ & $0.95 \pm 0.03$ \\
\hline G5 & $178.90 \pm 9.87$ & $38.42 \pm 1.65$ & $209.50 \pm 19.20 * *$ & $809.99 \pm 65.30$ & $0.11 \pm 0.00$ & $7.72 \pm 0.16$ & $3.71 \pm 0.07$ & $4.01 \pm 0.19$ & $0.94 \pm 0.05$ \\
\hline G6 & $152.26 \pm 9.94$ & $44.70 \pm 2.06$ & $213.98 \pm 24.93^{*}$ & $699.43 \pm 109.63$ & $0.13 \pm 0.01$ & $8.13 \pm 0.16$ & $3.73 \pm 0.05$ & $4.40 \pm 0.12$ & $0.85 \pm 0.02$ \\
\hline
\end{tabular}

Analysis of the hepatic and cardiac biomarkers after consecutive 24 days of treatment of the test formulation in male SD rats. All the values are represented as mean \pm SEM ( $\mathrm{n}=8$ ). Group; G1: Normal control; G2: Disease control; G3: Levamisole; G4: Biofield Energy Treated test formulation; G5: Untreated test formulation; G6: Biofield Energy Treatment per se at day -15; and G7: Biofield Energy Treated test formulation at day -15. SGOT: Serum glutamic oxaloacetic transaminase; SGPT: Serum glutamate-pyruvate transaminase; ALP: Alkaline phosphatase; CK-MB: Creatine kinase-myocardial band; Tot. BL: Total bilirubin; Tot. Prot.: Total protein; A: Albumin; G: Globulin; A/G: Albumin/Globulin ratio; U/L: Unit per liter; mg/dL: Milligram per deciliter; * $p \leq 0.05$, ${ }^{* *} p \leq 0.01$, and $* * * p \leq 0.001$ denoted as statistically significant as compared to the disease control.

\subsection{Measurement of Sex Hormone}

The effect of the test formulation on testosterone is shown in the Figure 3. An increasing trend of the testosterone was observed across the tested groups compared to the disease control (G2). The level of testosterone was significantly increased by $83.68 \%, 305.98 \%, 1271.03 \%(p<0.001)$ and 

on Various Biomarkers in Male Sprague Dawley Rats: Potential Role of the Trivedi Effect ${ }^{\mathbb{B}}$

$745.35 \%(p<0.05)$, in the $\mathrm{G} 4, \mathrm{G} 5, \mathrm{G} 6$, and $\mathrm{G} 7$, respectively compared to the G2 group. Ashwagandha (Withania somnifera) has been described in traditional Indian Ayurvedic medicine as an aphrodisiac that can be used to treat male sexual dysfunction and infertility. From the scientific literature it was evidenced that ashwagandha root extract has increased in sperm concentration, ejaculate volume, and motile sperm count and an increase the serum level of testosterone [52]. Cinar et al. [53], reported that the

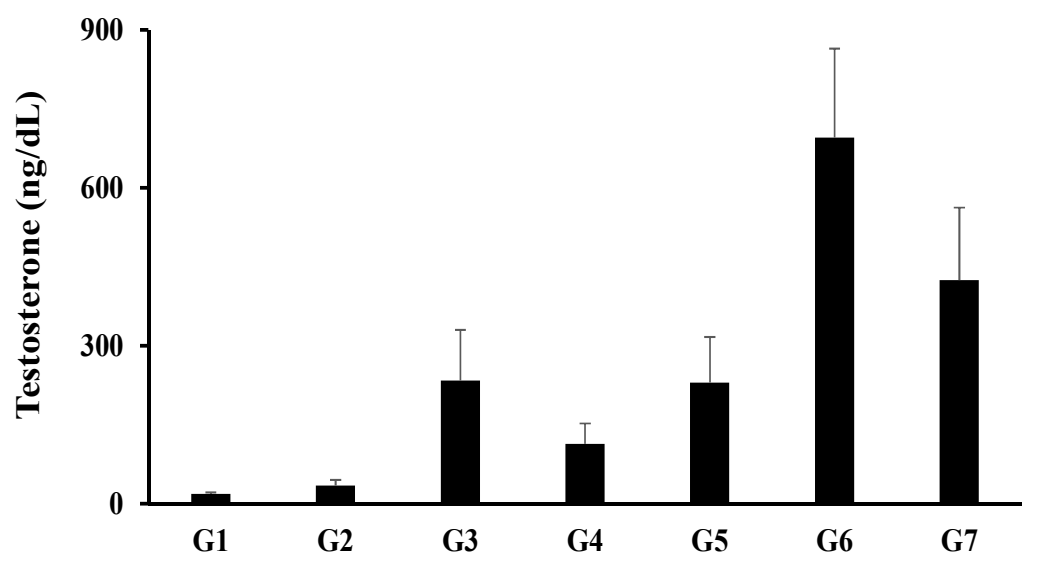

Figure 3. The effect of the test formulation on testosterone after consecutive 24 days of treatment in male SD rats. G1: Normal control; G2: Disease control; G3: Levamisole; G4: Biofield Energy Treated test formulation; G5: Untreated test formulation; G6: Biofield Energy Treatment per se at day -15; and G7: Biofield Energy Treated test formulation at day -15 . All the values are represented as mean $\pm S E M(n=8),{ }^{*} p \leq 0.05$ and $*^{*} p \leq 0.01$ (compared to the disease control).

\subsection{Measurement of Antioxidant Profile by ELISA}

The effect of the test formulation on various antioxidant enzymes like SOD, LPO, and CAT in male SD rats is demonstrated in the Figure 4. The level of LPO was significantly reduced by $11.98 \%$ and $24.15 \%$ in the Biofield Energy Treatment per se at day -15 (G6) and Biofield Energy

A. Catalase

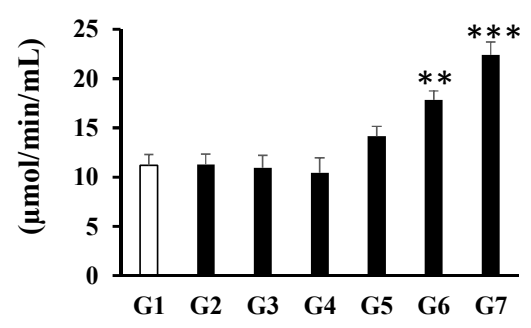

B. SOD

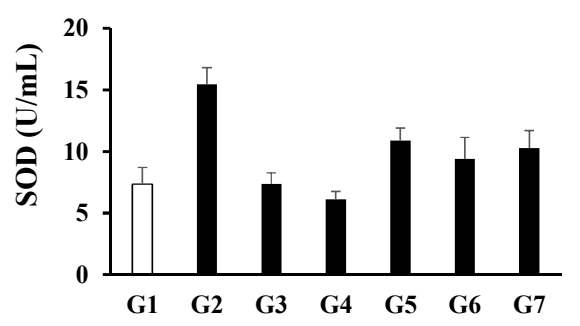

Treated test formulation at day -15 (G7), respectively compared to the disease control (G2). No positive trend was observed in case of SOD. The level of CAT enzyme was significantly increased by $57.91 \%(p<0.01)$ and $98.51 \%$ $p<0.001)$ in the G6 and G7, respectively compared to the disease control Group (G2).

Figure 4. The effect of the test formulation on anti-oxidative markers (A. CAT, B. SOD, and C. LPO) after 24 consecutive days of treatment in male SD rats. All the values are represented as mean $\pm \operatorname{SEM}(n=8) ; * * p<0.01$ and $* * * p<0.001$ (compared to the disease control).

\section{Conclusions}

Based on the current study findings, the IgM level was significantly increased by $13.07 \%$ and $16.34 \%$ in the Biofield Energy Treated test formulation (G4) and Biofield Energy Treated test formulation at day -15 (G7), respectively compared to the disease control group (G2). The expression of the cellular biomarkers like $\mathrm{CD} 4^{+}$and $\mathrm{CD} 8^{+}$was altered minimally in the Biofield Energy Treated test formulation group compared to the disease control. The Biofield Energy
Treated test formulation group (G4) showed significant increase the levels of TLC $(19.35 \%)$ and neutrophils $(31.53 \%)$, and reduce the levels of lipid biomarkers like TC, TG, and VLDL by $18.18 \%, 46.33 \%$, and $46.41 \%$, respectively compared to the disease control group (G2). Moreover, the levels of SGOT, SGPT, ALP, and CK-MB were significantly decreased by $29.44 \%, 25.54 \%, 27.97 \%$, and $36.07 \%$, respectively in the G7 group compared to the G2 group. The level of the hepatic enzyme like ALP was significantly reduced by $33.65 \%$ in the G4 group compared to the G2 group. Further, testosterone was significantly 
increased by $83.68 \%$ and $745.35 \%$ in the G4 and G7, respectively compared to the G2 group. The level of catalase was significantly increased by $57.91 \%$ and $98.51 \%$ in the Biofield Energy Treatment group per se at day -15 (G6) and $\mathrm{G} 7$, respectively compared to the $\mathrm{G} 2$ group.

Overall, it can be concluded that the novel herbomineral formulation and animals per se after treatment with the Trivedi Effect ${ }^{\circledR}$-Biofield Energy Healing remotely by the seven Biofield Energy Healers enhanced the herbomineral test formulation's anti-inflammatory and immunomodulatory properties. Therefore, the Biofield Energy Treated test formulation and animals per se may act as an effective antiinflammatory and immunomodulatory product, and it can be used as a Complementary and Alternative Medicine (CAM) with a safe therapeutic index for various autoimmune disorders such as Lupus, Systemic Lupus Erythematosus, Fibromyalgia, Addison Disease, Hashimoto Thyroiditis, Celiac Disease (gluten-sensitive enteropathy), Multiple Sclerosis, Dermatomyositis, Graves' Disease, Myasthenia Gravis, Pernicious Anemia, Aplastic Anemia, Scleroderma, Psoriasis, Rheumatoid Arthritis, Reactive Arthritis, Type 1 Diabetes, Sjogren Syndrome, Crohn's Disease, Vasculitis, Vitiligo, Chronic Fatigue Syndrome and Alopecia Areata, as well as inflammatory disorders such as Irritable Bowel Syndrome (IBS), Asthma, Ulcerative Colitis, Alzheimer's Disease, Parkinson's Disease, Atherosclerosis, Dermatitis, Hepatitis, and Diverticulitis. Further, the Biofield Energy Healing Treated test formulation can also be used in the prevention of immune-mediated tissue damage in cases of organ transplants (for example heart transplants, kidney transplants, and liver transplants), for anti-aging, stress prevention and management, and in the improvement of overall health and Quality of Life (QoL).

\section{Abbreviations}

Na-CMC: Sodium carboxymethyl cellulose; SD: Sprague Dawley; TC: Total cholesterol; TG: Triglycerides; LDL: Low density lipoprotein; HDL: High density lipoprotein; VLDL: Very low density lipoprotein; ALP: Alkaline phosphatase; SGOT: Serum glutamic oxaloacetic transaminase; SGPT: Serum glutamic pyruvic transaminase; TLC: Total leukocyte count; DLC: Differential leukocyte count; CK-MB: Creatine kinase myocardium band; CAT: Catalase; SOD: Superoxide dismutase; LPO: Lipid peroxidation; CD: Cluster differentiation

\section{Acknowledgements}

The authors are gratefully acknowledged to Trivedi science, Trivedi Global, Inc., and Trivedi master wellness and to Dabur Research Foundation (DRF), India for their support.

\section{References}

[1] Janeway CA Jr (2001) How the immune system protects the host from infection. Microbes Infect 3: 1167-1171.
[2] William JE (2001) Review of antiviral and immunomodulatory properties of plants of the Peruvian rainforest. Alter Med Rev 6: 567-579.

[3] Mahima, Rahal A, Deb R, Latheef SK, Abdul Samad H, Tiwari R, Verma AK, Kumar A, Dhama K (2012) Immunomodulatory and therapeutic potentials of herbal, traditional/indigenous and ethnoveterinary medicines. Pak J Biol Sci 15: 754-774.

[4] Sharma ML, Rao CS, Duda PL (1994) Immunostimulatory activity of Picrorhiza kurroa leaf extract. J Ethnopharmacol 41: 185-192.

[5] Wang JZ, Mao XJ, Ito H, Shimura K (1991) Immunomodulatory activity of polysaccharide from Acanthopanex obovatus roots. Planta Med 57: 335-336.

[6] Simon R (2011) Genomic biomarkers in predictive medicine: An interim analysis. EMBO Mol Med 3: 429-435.

[7] Konstantinidis TG, Tsigalou C, Bisiklis A, Romanidou G, Konstantinidou E, Parasidis T, Gioka T, Kampouromiti G, Constantinidis TC, Cassimos DC (2012) Autoantibodies in patients with asthma: Is there a link between asthma and autoimmunity? Int J Immunological Studies (Article in press). 6.

[8] Trakhtenberg EF, Goldberg JL (2011) Immunology. Neuroimmune communication. Science 334: 47-48.

[9] Berghella AM, Contasta I, Marulli G, D'Innocenzo C, Garofalo F, Gizzi F, Bartolomucci M, Laglia G, Valeri M, Gizzi M, Friscioni M, Barone M, Beato TD, Secinaro E, Pellegrini P (2014) Ageing gender-specific "biomarkers of homeostasis", to protect ourselves against the diseases of the old age. Immun Ageing 11: 3 .

[10] Houston M (2014) The role of nutrition and nutraceutical supplements in the treatment of hypertension. World J Cardiol 6: $38-66$.

[11] Bishop WM, Zubeck HM (2012) Evaluation of microalgae for use as nutraceuticals and nutritional supplements. J Nutr Food Sci 2: 147.

[12] Houston, M (2013) Nutrition and nutraceutical supplements for the treatment of hypertension: Part I. 15: 752-757.

[13] Davis L, Kuttan G (2000) Immunomodulatory activity of Withania somnifera. J Ethnopharmacol 71: 193-200.

[14] Heroor S, Beknal A, Mahurkar N (2012) Preliminary investigation for immunomodulation of methanolic extracts of leaves and flowers of Pongamia glabra Vent. in mice model. Adv Lif Sci 2: 170-173.

[15] Glotter E, Abraham A, Guenzberg IK (1977) Naturally occurring steroidal lactones with 17 a-oriented side chain structure of withanolide E \& related compounds. J Chem Soc Perkins Trans 1: 341-346.

[16] Sohat B, Gitter E, Abraham A, Lavie D (1967) Antitumor activity of withaferin A. Can Chemother Rep 51: 51271-51276.

[17] James SJ, Swenseid M, Makinodan T (1987) Macrophagemediated depression of T-cell proliferation in zinc-deficient mice. J Nutr 117: 1982-1988.

[18] Engle TE, Nockels DF, Kimberling CV, Weaber DL, Johnson AB (1997) Zinc repletion with organic and inorganic forms of zinc and protein turnover in marginally zinc-deficient calves. $\mathrm{J}$ Anim Sci 75: 3074-3081. 

on Various Biomarkers in Male Sprague Dawley Rats: Potential Role of the Trivedi Effect ${ }^{\circledR}$

[19] Salimian J, Arefpour MA, Riazipour M, Poursasan N (2004) Immunomodulatory effects of selenium and vitamin $\mathrm{E}$ on alterations in $\mathrm{T}$ lymphocyte subsets induced by $\mathrm{T}-2$ toxin. Immunopharmacol Immunotoxicol 36: 275-281.

[20] Sugimoto J, Romani AM, Valentin-Torres AM, Luciano AA, Ramirez Kitchen CM, Funderburg N, Mesiano S, Bernstein HB (2012) Magnesium decreases inflammatory cytokine production: A novel innate immunomodulatory mechanism. J Immunol 188: 6338-6346.

[21] Quinn PJ (1990) Mechanism of action of some immunomodulators used in veterinary medicine. Adv Vet Sci Comp Med 35: 43-99.

[22] Wang JZ, Mao XJ, Ito H, Shimura K (1991) Immunomodulatory activity of polysaccharide from Acanthopanex obovatus roots. Planta Med 57: 335-336.

[23] Rubik B (1994) Manual healing methods. Alternative medicine: Expanding medical horizons, Washington, DC, US Government Printing Office, NIH Publication No. 094-066.

[24] Cooper EL (2007) The immune system and complementary and alternative medicine. Evid Based Complement Alternat Med 4: 5-8

[25] Trivedi MK, Patil S, Shettigar H, Mondal SC, Jana S (2015) In vitro evaluation of biofield treatment on viral load against human immunodeficiency-1 and cytomegalo viruses. American Journal of Health Research 3: 338-343.

[26] Trivedi MK, Patil S, Shettigar H, Mondal SC, Jana S (2015) In vitro Evaluation of biofield treatment on Enterobacter cloacae: Impact on antimicrobial susceptibility and biotype. J Bacteriol Parasitol 6: 241.

[27] Trivedi MK, Patil S, Shettigar H, Mondal SC, Jana S (2015) Evaluation of biofield modality on viral load of hepatitis B and $\mathrm{C}$ viruses. J Antivir Antiretrovir 7: 083-088.

[28] Trivedi MK, Patil S, Shettigar H, Mondal SC, Jana S (2015) An impact of biofield treatment: Antimycobacterial susceptibility potential using BACTEC 460/MGIT-TB system. Mycobact Dis 5: 189.

[29] Trivedi MK, Branton A, Trivedi D, Nayak G, Mondal SC, Jana S (2015) Evaluation of antibiogram, genotype and phylogenetic analysis of biofield treated Nocardia otitidis. Biol Syst Open Access 4: 143.

[30] Trivedi MK, Branton A, Trivedi D, Nayak G, Gangwar M, Jana S (2015) Antibiogram, biochemical reactions, and genotypic pattern of biofield treated Pseudomonas aeruginosa. J Trop Dis 4: 181.

[31] Trivedi MK, Patil S, Tallapragada RM (2013) Effect of bio field treatment on the physical and thermal characteristics of vanadium pentoxide powders. J Material Sci Eng S 11: 001.

[32] Trivedi MK, Branton A, Trivedi D, Shettigar H, Bairwa K, Jana S (2015) Fourier transform infrared and ultravioletvisible spectroscopic characterization of biofield treated salicylic acid and sparfloxacin. Nat Prod Chem Res 3: 186.

[33] Trivedi MK, Tallapragada RM, Branton A, Trivedi D, Nayak G, Latiyal O, Jana S (2015) Potential impact of biofield treatment on atomic and physical characteristics of magnesium. Vitam Miner 3: 129.

[34] Trivedi MK, Branton A, Trivedi D, Nayak G, Sethi KK, Jana
S (2016) Gas chromatography-mass spectrometry based isotopic abundance ratio analysis of biofield energy treated methyl-2-napthylether (Nerolin). American Journal of Physical Chemistry 5: 80-86.

[35] Trivedi MK, Branton A, Trivedi D, Nayak G, Panda P, Jana S (2016) Gas chromatography-mass spectrometric analysis of isotopic abundance of ${ }^{13} \mathrm{C},{ }^{2} \mathrm{H}$, and ${ }^{18} \mathrm{O}$ in biofield energy treated $p$-tertiary butylphenol (PTBP). American Journal of Chemical Engineering 4: 78-86.

[36] Trivedi MK, Branton A, Trivedi D, Nayak G, Mondal SC, Jana S (2015) Evaluation of biochemical marker - glutathione and DNA fingerprinting of biofield energy treated Oryza sativa. American Journal of BioScience 3: 243-248.

[37] Trivedi MK, Branton A, Trivedi D, Nayak G, Gangwar M, Jana S (2016) Molecular analysis of biofield treated eggplant and watermelon crops. Adv Crop Sci Tech 4: 208.

[38] Trivedi MK, Tallapragada RM, Branton A, Trivedi D, Nayak G, Latiyal O, Jana S (2015) Physical, atomic and thermal properties of biofield treated lithium powder. J Adv Chem Eng 5: 136.

[39] Trivedi MK, Tallapragada RM, Branton A, Trivedi D, Nayak G, Latiyal O, Jana S (2015) Evaluation of biofield energy treatment on physical and thermal characteristics of selenium powder. Journal of Food and Nutrition Sciences 3: 223-228.

[40] Trivedi MK, Tallapragada RM, Branton A, Trivedi D, Nayak G, Mishra RK, Latiyal O, Jana S (2015) Physicochemical characterization of biofield energy treated calcium carbonate powder. American Journal of Health Research 3: 368-375.

[41] Ladics GS (2007) Primary immune response to sheep red blood cells (SRBC) as the conventional T-cell dependent antibody response (TDAR) test. J Immunotoxicol 4: 149-152.

[42] King EJ, Armstrong AR (1934) Estimation of alkaline phosphatase. Canad Med Assoc J 311: 152-156.

[43] Folch J, Lees M, Sloane Stanley GH (1957) A simple method for the isolation and purification of total lipids from animal tissue. J Biol Chem 226: 497-509.

[44] Devasagayam TPA, Tarachand U (1987) Decreased lipid peroxidation in the rat kidney during gestation. Biochem Biophys Res Commun 145: 134-138.

[45] Marklund S, Marklund G (1974) Involvement of superoxide anion radical in the autooxidation of pyrogallol and a convenient assay for superoxide dismutase. Eur J Biochem 47: 469-474.

[46] Sinha AK (1972) Colorimetric assay of catalase. Anal Biochem 47: 389-394.

[47] Yamada K, Hung P, Park TK, Park PJ, Limb BO (2011) A comparison of the immunostimulatory effects of the medicinal herbs echinacea, ashwagandha and brahmi. J Ethnopharmacol 137: 231-235.

[48] Solomons NW (1998) Mild human zinc deficiency produces an imbalance between cell-mediated and humoral immunity. Nutr Rev 56: 27-28.

[49] Jung Y, Rothenberg ME (2014) Roles and regulation of gastrointestinal eosinophils in immunity and disease. $\mathrm{J}$ Immunol 193: 999-1005. 
[50] Galioto AM, Hess JA, Nolan TJ, Schad GA, Lee JJ, Abraham D (2006) Role of eosinophils and neutrophils in innate and adaptive protective immunity to larval Strongyloides stercoralis in mice. Infect Immun 74: 5730-5738.

[51] Sultana N, Shimmi AC, Hossain MT, Akhtar J (2012) Effects of ashwagandha (Withania somnifera) root extract on some serum liver marker enzymes (AST, ALT) in gentamicin intoxicated rats. J Bangladesh Soc Physiol 7: 1-7.

[52] Ambiye VR, Langade D, Dongre S, Aptikar P, Kulkarni M, Dongre A (2013) Clinical evaluation of the spermatogenic activity of the root extract of ashwagandha (Withania somnifera) in oligospermic males: A pilot study. Evid Based Complement Alternat Med 2013: 571420.
[53] Cinar V, Polat Y, Baltaci AK, Mogulkoc R (2011) Effects of magnesium supplementation on testosterone levels of athletes and sedentary subjects at rest and after exhaustion. Biol Trace Elem Res 140: 18-23.

[54] Garcia PC, Piffer RC, Gerardin DC, Sankako MK, Alves de Lima RO, Pereira OC (2012) Could zinc prevent reproductive alterations caused by cigarette smoke in male rats? Reprod Fertil Dev 24: 559-567.

[55] Jana K, Samanta PK, Manna I, Ghosh P, Singh N, Khetan RP, Ray BR (2008) Protective effect of sodium selenite and zinc sulfate on intensive swimming-induced testicular gamatogenic and steroidogenic disorders in mature male rats. Appl Physiol Nutr Metab 33: 903-914. 